\title{
Treatment effect bias in randomised controlled trials using surrogate outcomes: a preliminary cohort study analysis
}

\author{
Oriana Ciani*, Rod S Taylor \\ From Clinical Trials Methodology Conference 2011 \\ Bristol, UK. 4-5 October 2011
}

\section{Background}

Ideally, decisions on the value of health technologies should be based on evidence from well-conducted clinical trials that assess clinically important final patientrelevant outcomes, such as mortality or impaired quality of life. Pressure to reduce the delay in the availability of technologies to patients has led to an increased reliance on the use of surrogate outcomes [1]. A key tenant of surrogate outcomes is unbiased quantification of the predictive treatment effect on the final patient-relevant clinical outcomes. This study compares the treatment outcome of trials that use a surrogate versus a final patient-relevant primary outcome.

\section{Materials and methods}

We searched for all randomized controlled trials (RCTs) published in JAMA, NEJM, Lancet, BMJ, PLoS Medicine and Annals of Internal Medicine in 2005 and 2006 [2]. We distinguished between trials that used a surrogate or a patient-relevant primary outcome. An outcome was defined as a surrogate if it did not directly measure "how a patient feels, functions, or survives" [3] or was judged to be a substitute and predictive of a final outcome [1]. We excluded non-RCTs, composite (of both surrogate and final) outcomes, economic evaluations and non-interventional technologies. Surrogate and final outcome trials were matched on patient population, intervention, journal and year of publication. In this preliminary analysis we compare the two groups of trials

\footnotetext{
* Correspondence: oriana.ciani@pcmd.ac.uk

Peninsula Technology Assessment Group (PenTAG), Institute of Health Services Research, Peninsula College of Medicine \& Dentistry, University of Exeter, Exeter, Devon, EX14 3JJ, UK
}

\begin{tabular}{|c|c|c|}
\hline & $\begin{array}{c}\text { Surrogate Trials }(\mathrm{N}=138) \\
\mathrm{N}(\%)\end{array}$ & $\begin{array}{c}\text { Final Trials }(\mathrm{N}=132) \\
\mathrm{N}(\%)\end{array}$ \\
\hline \multicolumn{3}{|l|}{$\begin{array}{l}\text { Intervention clinical } \\
\text { area }\end{array}$} \\
\hline Cardiovascular & $31(22)$ & $31(23)$ \\
\hline Endocrinology & $11(8)$ & $4(3)$ \\
\hline $\begin{array}{l}\text { Gastrology/ } \\
\text { hepatology }\end{array}$ & $11(8)$ & $11(8)$ \\
\hline Infectious disease & $28(20)$ & $28(21)$ \\
\hline $\begin{array}{l}\text { Nephrology/ } \\
\text { urology }\end{array}$ & $4(3)$ & $4(3)$ \\
\hline Neurology & $2(1)$ & $3(2)$ \\
\hline Obstetrics & $5(4)$ & $5(4)$ \\
\hline Oncology & $4(3)$ & $4(3)$ \\
\hline Other & $36(26)$ & $36(27)$ \\
\hline Pulmunology & $6(4)$ & $6(5)$ \\
\hline \multicolumn{3}{|l|}{$\begin{array}{l}\text { Population clinical } \\
\text { area }\end{array}$} \\
\hline Cardiovascular & $34(25)$ & $31(23)$ \\
\hline Endocrinology & $14(10)$ & $9(7)$ \\
\hline $\begin{array}{l}\text { Gastrology/ } \\
\text { hepatology }\end{array}$ & $9(7)$ & 10(8) \\
\hline Infectious disease & $21(15)$ & $21(16)$ \\
\hline $\begin{array}{l}\text { Nephrology/ } \\
\text { urology }\end{array}$ & $2(1)$ & $5(4)$ \\
\hline Neurology & $2(1)$ & $2(2)$ \\
\hline Obstetrics & $7(5)$ & $8(6)$ \\
\hline Oncology & $4(3)$ & $4(3)$ \\
\hline Other & $36(26)$ & $36(27)$ \\
\hline Pulmunology & $9(7)$ & $6(5)$ \\
\hline \multicolumn{3}{|l|}{ Journal } \\
\hline Annals & $14(10)$ & 10(8) \\
\hline BMJ & $11(8)$ & $14(11)$ \\
\hline JAMA & $31(22)$ & $31(23)$ \\
\hline Lancet & $28(20)$ & $28(21)$ \\
\hline
\end{tabular}


Table 1 Characteristics of included surrogate and final trials. (Continued)

\begin{tabular}{lcc}
\hline NEJM & $51(37)$ & $49(37)$ \\
PLoS & $3(2)$ & - \\
\hline Year & & \\
2005 & $64(46)$ & $63(48)$ \\
2006 & $74(54)$ & $69(52)$ \\
\hline
\end{tabular}

Surrogate trials were less likely to have adequate evidence of randomisation sequence generation and adopt the ITT principle. We also found clear evidence that final trials were more likely to observe a non-statistically significant ('neutral') treatment effect than surrogate trials ( $49 \%$ vs $23 \%$ ) (Table 2).

based on the statistical significance and direction of their outcome results.

\section{Results}

Of the 639 citations identified by our searches, we included 138 trials that used a primary surrogate outcome ('surrogate trials') and 132 trials that used a final patient-relevant outcomes ('final trials'). Table 1 summarises the trial characteristics used for matching. Other trial characteristics also appeared to be well balanced except for the length of follow-up (i.e. more studies with follow up $<30$ days and $>1$ year for final trials).

\section{Conclusions}

This preliminary analysis supports our initial hypothesis that the use of surrogate outcomes is more likely to lead statistically significant treatment effects than patientrelevant primary outcomes. We are currently undertaking additional analysis using actual effect sizes in metaanalytic/meta-regression framework. These results have important implications for payers faced with making

Table 2 Comparison of outcome results.

\begin{tabular}{lccc}
\hline & $\begin{array}{c}\text { Surrogate Trials } \\
(\mathbf{N}=\mathbf{1 3 8}) \mathbf{N}(\%)\end{array}$ & $\begin{array}{c}\text { Final Trials } \\
(\mathbf{N}=\mathbf{1 3 2}) \mathbf{N}(\%)\end{array}$ & $\begin{array}{c}\boldsymbol{P} \text { - } \\
\text { value }^{\boldsymbol{a}}\end{array}$ \\
\hline $\begin{array}{l}\text { Study outcome } \\
\text { Positive }\end{array}$ & $49(36)$ & $41(31)$ & $0.006^{\mathrm{c}}$ \\
Negative & $5(4)$ & $4(3)$ & \\
Neutral & $32(23)$ & $65(49)$ & \\
\hline Risk of bias & $95(69)$ & $106(80)$ & 0.031 \\
$\begin{array}{l}\text { Statement of ITT } \\
\text { Automated }\end{array}$ & $82(59)$ & $93(70)$ & 0.058 \\
sequence generation & $96(70)$ & $97(63)$ & 0.476 \\
$\begin{array}{l}\text { Allocation } \\
\text { concealment }\end{array}$ & $72(52)$ & $60(45)$ & 0.27 \\
Blinding/Placebo & &
\end{tabular}

${ }^{\mathrm{a}}$ Chi-square test, unless otherwise specified.

b'positive': treatment group superior to control ( $P \leq 0.05)$; 'negative', control group superior to treatment $(P \leq 0.05)$; 'neutral', treatment and control indifferent, $\mathrm{P}>0.05$ ).

${ }^{\mathrm{C}}$ Fisher's exact test. Multiple-interventions trials are excluded from this comparison. coverage decisions on the effectiveness and cost-effectiveness of new treatments based on surrogate rather than final clinical trials data.

\section{Acknowledgements}

We thank Toby Pavey for the assistance in data checking and professor Peter Gøtzsche and co-authors who kindly provided access to the data files of their study.

Ciani O. is currently in receipt of a Peninsula College of Medicine and Dentistry PhD studentship.

Published: 13 December 2011

\section{References}

1. Elston J, Taylor RS: Use of surrogate outcomes in cost-effectiveness models: A review of United Kingdom health technology assessment reports. Int J Technol Assess Health Care 2009, 25:6-13.

2. la Cour JL, Brok J, Gøtzsche PC: Inconsistent reporting of surrogate outcomes in randomised clinical trials: cohort study. BMJ 2010, 341 c3653.

3. Temple RJ: A regulatory authority's opinion about surrogate endpoints. In Clinical Measurement in Drug Evaluation. New York: John Wiley and Sons Inc;Nimmo WS, Tucker GT 1995:3-22.

doi:10.1186/1745-6215-12-S1-A73

Cite this article as: Ciani and Taylor: Treatment effect bias in

randomised controlled trials using surrogate outcomes: a preliminary cohort study analysis. Trials 2011 12(Suppl 1):A73.

\section{Submit your next manuscript to BioMed Central} and take full advantage of:

- Convenient online submission

- Thorough peer review

- No space constraints or color figure charges

- Immediate publication on acceptance

- Inclusion in PubMed, CAS, Scopus and Google Scholar

- Research which is freely available for redistribution 